\title{
Pour un développement des études de technologie quantitative
}

Paul Pascon

\section{(2) OpenEdition \\ Journals}

Édition électronique

URL : https://journals.openedition.org/tc/1008

DOI : $10.4000 /$ tc. 1008

ISSN : 1952-420X

Éditeur

Éditions de l'EHESS

\section{Édition imprimée}

Date de publication : 1 juin 1984

ISSN : 0248-6016

\section{Référence électronique}

Paul Pascon, "Pour un développement des études de technologie quantitative », Techniques \& Culture [En ligne], 3 | 1984, mis en ligne le 26 janvier 2006, consulté le 29 septembre 2022. URL : http:// journals.openedition.org/tc/1008; DOI : https://doi.org/10.4000/tc.1008

\section{Ce document a été généré automatiquement le 29 septembre 2022.}

Tous droits réservés 


\title{
Pour un développement des études de technologie quantitative
}

\author{
Paul Pascon
}

